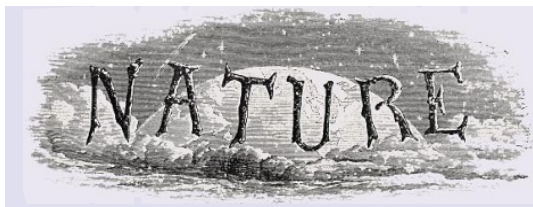

100 YEARS AGO

The "red rain" which fell in many parts of Italy and extended as far as Vienna and other central European stations on the evening of March 10, 1901, has been subsequently studied by Prof. N. Passerini, and an account of the phenomena is now given by him in the Bolletino mensuale of the Italian Meteorological Society. The phenomenon appears to have travelled slowly from south to north... Prof. Passerini found that the precipitation of the earthy substance was accompanied with very little rain, and a rough analysis showed it to contain about 44 per cent. of fine sand, 32 per cent. of argillaceous matter, 12 per cent. of calcareous matter and about 10 per cent. of organic and volatile substances destroyed by calcination. The red colour was probably due to ferric hydrate... It is suggested that the material deposited in this and other so-called "rains of blood" that have occurred at different times in Italy may probably have been transported by a cyclonic disturbance, and may have had its origin in the equatorial regions of Africa or America.

From Nature 10 April 1902.

\section{YEARS AGO}

Recently, while continuing the search for additional Lower Miocene fossil fruits and seeds in the deposits on Rusinga and M'fwangano Islands in Lake Victoria, in order to obtain more data concerning the environmental conditions under which the Miocene ape Proconsul lived, we have found some remarkable fossils of insects and other soft-bodied invertebrates. This discovery is of unusual interest, not only because it is believed to be the first of its kind in Africa, but also because of the very unusual state of preservation of the material. Most fossil insect remains - other than those preserved in Oligocene ambers - have been found in a somewhat crushed and distorted condition in laminated rocks. In the present case the fossils, in spite of their soft-bodied nature during life, have retained their natural shape in a quite surprising manner... Some twenty specimens of invertebrates have so far been obtained, and it is anticipated that many more will be found as the work of the British Kenya Miocene Expedition continues. The material at present includes....representatives of Orthoptera, Coleoptera, Blattoidea and, perhaps the most surprising of all, what appears to be a fossil earthworm. L. S. B. Leakey

From Nature 12 April 1952. to dynamo theory, helical vortex flows like these should be very efficient in maintaining the geomagnetic field, and indeed helical vortices are prominent in numerical models of the geodynamo ${ }^{7}$.

What are the prospects for capturing even more detailed images of the geodynamo? Improved spatial resolution is unlikely to be the answer, because it is difficult to see smaller-scale behaviour of the core magnetic field through the planet's magnetized crust. But by combining data from satellite missions with measurements of the palaeomagnetic field recorded in lava and sediments ${ }^{8}$, there is potential for extending our picture of the geodynamo over thousands, even millions, of years into the past.
Peter Olson is in the Morton K. Blaustein Department of Earth and Planetary Sciences, Johns Hopkins University, Baltimore,

Maryland 21218, USA.

e-mail:olson@jhu.edu

$$
\begin{aligned}
& \text { 1. Hulot, G., Eymin, C., Langlais, B., Mandea, M. \& Olsen, N. } \\
& \text { Nature 416, 620-623 (2002). } \\
& \text { 2. Gubbins, D. Nature 326, 167-169 (1987). } \\
& \text { 3. Glatzmaier, G. A., Coe, R. C., Hongre, L. \& Roberts, P. H. } \\
& \text { Nature 401, 885-890 (1999). } \\
& \text { 4. Merrill, R. T., McElhinny, M. W. \& McFadden, P. L. } \\
& \text { The Magnetic Field of the Earth: Paleomagnetism, the Core } \\
& \text { and the Deep Mantle (Academic, San Diego, 1996). } \\
& \text { 5. Halley, E. Phil. Trans. R. Soc. Lond. A 16, 563-578 (1692). } \\
& \text { 6. Jault, D., Gire, C. \& LeMouel, J.-L. Nature 333, 353-356 } \\
& \text { (1988). } \\
& \text { 7. Roberts, P. \& Glatzmaier, G. A. Rev. Mod. Phys. 72, } \\
& \text { 1081-1123 (2000). } \\
& \text { 8. Constable, C. G., Johnson, C. L. \& Lund, S. P. Phil. Trans. R. } \\
& \text { Soc. Lond. A 358, 991-1008 (2000). }
\end{aligned}
$$

Global change

\title{
Carbon dioxide goes with the flow
}

\author{
John Grace and Yadvinder Malhi
}

\section{Measurements of the rate at which carbon dioxide is released from rivers running through tropical forests provide a surprise. They will help in developing an improved picture of the carbon cycle.}

$\mathrm{R}$ ainforests contain not only trees but also lots of water, largely in the form of river systems. The Amazon is by far the largest such system in the world, contributing $20 \%$ of all water flowing from rivers to the ocean. But how this and other great rivers participate in the global carbon cycle is a puzzle - relatively small quantities of carbon are detected in the outflow, yet organic material from the adjacent forest is commonly observed as floating debris. On page 617 of this issue ${ }^{1}$, Richey et al. provide insight into the watery fate of the organic matter produced by the forest, showing that much of it is released into the atmosphere as $\mathrm{CO}_{2}$. There is some way to go, however, before we can balance the carbon-budget books.

The study ${ }^{1}$ focuses on the central part of the Amazon basin (see the map on page 617). The authors show that the river water contains high concentrations of $\mathrm{CO}_{2}$, which they infer is being released into the atmosphere at a surprisingly high rate per unit area - a rate that is comparable to that from respiration by soil organisms, and which contributes substantially to the 'decomposition flux' of $\mathrm{CO}_{2}$ from the basin as a whole.

The recognition that the forest exports carbon, which decomposes in water and is released as $\mathrm{CO}_{2}$, helps to reconcile some of the conflicting results from studies of the carbon cycle and carbon budget, both in the Amazon and on a global scale. The data concerned come from measurements by eddy covariance ${ }^{2,3}$ (direct measurements of $\mathrm{CO}_{2}$ flux made above the forest, using towers), analyses of forest inventories ${ }^{4}$ (calculations from repeated measurements of the number and size of trees in sample plots), and studies of the global atmosphere ${ }^{5}$ (calculations of the geographical distribution of $\mathrm{CO}_{2}$ sources and sinks made from frequent and precise measurements of concentration in the Earth's atmosphere).

Several studies of eddy covariance suggest that about $5 \times 10^{6} \mathrm{~g}$ of carbon accumulate per hectare per year in the dry-land - 'terra firme' — forests of the Amazon basin. This is a surprisingly large amount, but to our knowledge only two studies have produced much smaller estimates ${ }^{2}$. Although it is expected that the 'fertilization' that arises from increasing levels of $\mathrm{CO}_{2}$ in the atmosphere would enhance the uptake of carbon, with photosynthesis exceeding respiration, it seems from both calculations and experiments that this effect is rather small for mature forests ${ }^{6}$. If the high rate of carbon accumulation were to apply to the entire basin, we would have to conclude that the Amazon is a giant carbon sink, perhaps absorbing two-thirds of the world's fossilfuel emissions. This seems unlikely, and moreover is not consistent with either forest-inventory analyses or global atmospheric studies, which suggest that the Amazonian sink is much smaller. Richey et al. ${ }^{1}$ show that significant quantities of the carbon assimilated by the forest are almost certainly carried away, and decompose elsewhere. In other words, the eddy-covariance towers situated in the forests do not give a true picture of the overall decomposition.

These, however, are highly complicated issues, and inevitably there are questions to 


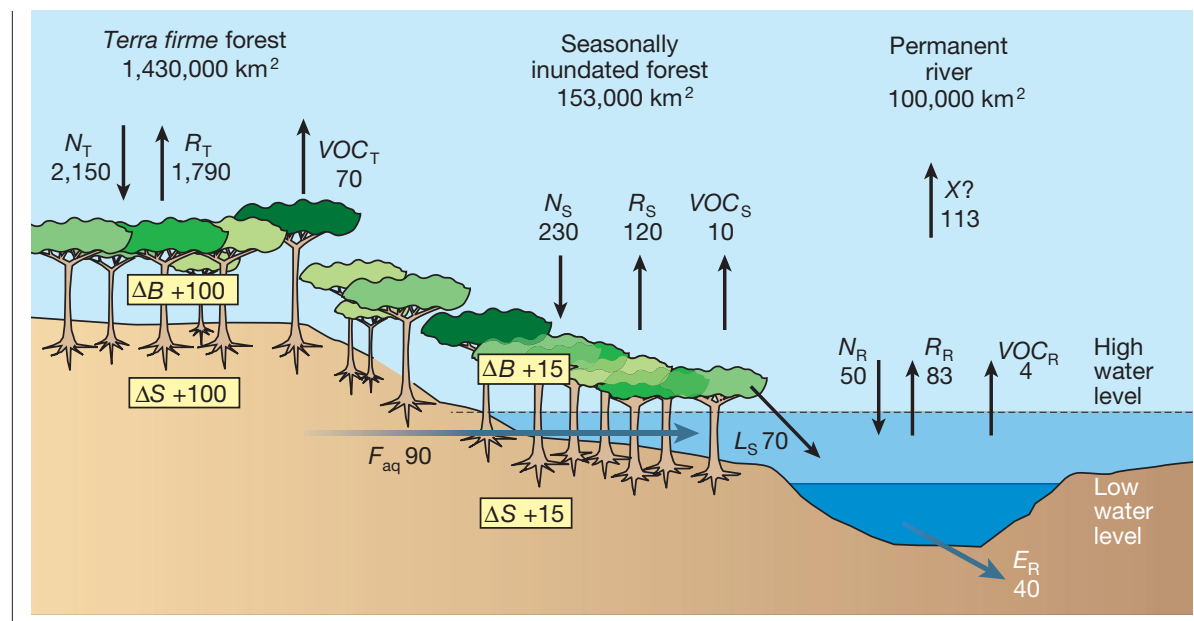

Figure 1 Estimates of carbon flows in the central Amazon basin. As defined by Richey et al. ${ }^{1}$, this is a region of 1.77 million $\mathrm{km}^{2}$, and here it is shown divided into terra firme forest $(\mathrm{T})$, seasonally inundated forest $(\mathrm{S})$ and permanent river $(\mathrm{R})$. All units are $10^{12} \mathrm{~g} \mathrm{C} \mathrm{yr}^{-1}$. The area of seasonally inundated forest $\left(153,000 \mathrm{~km}^{2}\right)$ represents the mean area that is flooded over the year. $N$, net primary productivity; $R$, heterotrophic respiration; VOC, flux of volatile organic compounds (methane, isoprene, monoterpenes); $F_{\mathrm{aq}}$, flow of carbon from forest to river as dissolved $\mathrm{CO}_{2}$ and dissolved organic carbon; $\Delta B$, net carbon accumulation in biomass; $\Delta S$, net carbon accumulation in soils; $L_{\mathrm{S}}$, direct litter flow from flooded and riverside forests into water; $E_{\mathrm{R}}$, net export of dissolved or inorganic carbon in the Amazon's main stream. $N_{\mathrm{T}}$ and $R_{\mathrm{T}}$ are derived from ref. 7. $N_{\mathrm{S}}$ per unit area is assumed to be the same as $N_{\mathrm{p}}$ (the net primary productivity of the terra firme forest ${ }^{8}$ ). $\Delta B$ and $\Delta S$ are derived from forest inventories and estimates of soil-carbon residence times ${ }^{9} . E_{\mathrm{R}}$ is scaled down from the estimate for the entire Amazon $\operatorname{basin}^{1} . X$ is a residual efflux from the river, which is required to account for the fact that the flux reported by Richey et al. is less than the carbon entering the river.

be asked about the new results. For instance, is the authors' method for calculating $\mathrm{CO}_{2}$ flux reliable? The method is the same as that used by oceanographers, and is relatively simple: flux is calculated as the difference in $\mathrm{CO}_{2}$ partial pressure between the water and the atmosphere (in this case, measured at 1,800 sites), multiplied by an exchange coefficient. As used by Richey et al. ${ }^{1}$, the calculation can be expected to yield a conservative estimate of $\mathrm{CO}_{2}$ flux under most conditions because the exchange coefficient is determined inside floating chambers, without normal air movement, so the true flux may be even higher.

To see the new work in a broader context, the central Amazon basin can be represented as a three-component system: the terra firme forest, the seasonally inundated forest and the permanent river. To try to identify the uncertainties in the carbon budget, we have combined Richey and colleagues' data on outgassing of $\mathrm{CO}_{2}$ by the river with published carbon fluxes over terra firme forest ${ }^{7}$ and textbook data on fluxes over inundated forest ${ }^{8}$. The outcome is shown in Fig. 1. We calculate that the residual carbon flux from the river, which must balance the inputs and outputs, is $1.13 \times 10^{14} \mathrm{~g} \mathrm{C} \mathrm{yr}^{-1}$. This suggests either that the authors' estimate of $\mathrm{CO}_{2}$ flux is indeed conservative, or that the calculated input of dissolved carbon from terra firme forest, estimated by Richey et al. as $40 \%$ of the total riverine $\mathrm{CO}_{2}$ flux, is too high.

Even taking the export of carbon into account, there remains a problem in balancing the books for terra firme forests. Net carbon uptake is often measured by eddy covariance as $500 \mathrm{gC} \mathrm{m}^{-2} \mathrm{yr}^{-1}$, of which about $70 \mathrm{~g}$ are accumulated in the biomass and $70 \mathrm{~g}$ in the soil carbon pool, $50 \mathrm{~g}$ are lost as volatile
T: he fundamental task of our immune system is to fight invading microorganisms while sparing normal components of our own tissues. For example, antibodies (also known as immunoglobulins) secreted by immune cells are usually directed towards molecules on pathogens but not those on 'self' tissues; selective binding of antibodies to the pathogens helps to destroy them. Numerous mechanisms, referred to collectively as immunological tolerance, normally safeguard against self-targeted immune responses. When these mechanisms fail, autoantibodies - self-reactive antibodies - are produced. In systemic autoimmune diseases such as rheumatoid arthritis, antibody molecules themselves are frequently the target of autoantibodies, and these anti-immunoglobulin autoantibodies compounds, and $60 \mathrm{~g}$ are exported to the river. This leaves $250 \mathrm{~g} \mathrm{C} \mathrm{m}^{-2} \mathrm{yr}^{-1}$ of carbon uptake as 'missing carbon', which must be accounted for. One possible explanation, which is currently being explored, is that, during the night, $\mathrm{CO}_{2}$-rich air in the forest canopy drains to valley bottoms and towards rivers.

Finally, to interpret fully the results of Richey et al., we need to know more about the origins of the $\mathrm{CO}_{2}$ that comes from the river. The sources are likely to be organic matter from terra firme forest, from inundated forest and from vegetation on the riverside and in the river itself. Richey et al. provide an estimate of the relative importance of these sources, but their figures are highly uncertain. We also need clarification on related questions, such as whether the carbon is young (from decaying litter) or old (from within the soil). Studies using chemical and isotopic tracers are the way forward in this respect.

John Grace and Yadvinder Malhi are at

the Institute of Ecology and Resource

Management, University of Edinburgh,

Edinburgh EH9 3JU, UK.

e-mail:jgrace@ed.ac.uk
1. Richey, J. E., Melack, J. M., Aufdenkampe, A. K., Ballester, V. M. \& Hess, L. L. Nature 416, 617-620 (2002)
2. Grace, J. et al. Science $270,778-780$ (1995)
3. Malhi, Y. et al. J. Geophys. Res. 103, 31593-31612 (1998).
4. Phillips, O. L. et al. Science 282, 439-442 (1998).
5. Gurney, K. R. et al. Nature $415,626-630$ (2002).
6. Lloyd, J. \& Farquhar, G. D. Funct. Ecol. 10, 4-32 (1996)
7. Malhi, Y. et al. Plant Cell Environ. 22, 715-740 (1999)
8. Junk, W. The Central Amazon Floodplain (Springer, Berlin, 1997)
9. Malhi, Y. \& Grace, J. Trends Ecol. Evol. 15, 332-337 (2000)

\section{Immunology \\ DNA drives autoimmunity \\ Carola G. Vinuesa and Christopher C. Goodnow}

In autoimmune diseases, a person's tissues are destroyed by their own immune system. IgG, a normal component of blood, provokes autoimmune responses when immune cells recognize it as a complex with DNA.

are known as rheumatoid factors. On page 603 of this issue, Leadbetter and colleagues ${ }^{1}$ reveal an unexpected mechanism that explains how immune cells might perceive antibodies as pathogens, provoking the production of autoantibodies.

B lymphocytes - the precursors of antibody-producing cells - must integrate signals from two classes of signal-detecting receptor protein before they proliferate and make antibodies that will be secreted into the bloodstream. This dual requirement is key to the immune system's ability to distinguish between foreign and self 'antigens' (molecules that elicit an immune response) ${ }^{2}$. Signal 1 comes from the binding of antigens directly to specific antigen receptors on B cells, namely cell-surface immunoglobulin molecules with variable antigen-binding 